\title{
Penalaran Statistik Pada Peserta Didik Kelas IX
}

\author{
1Fina Putri Damayanti, ${ }^{2}$ Widahyanti, ${ }^{3}$ Surya Sari Faradiba \\ 1,2,3Program Studi Pendidikan Matematika, FKIP, Universitas Islam Malang \\ ${ }^{1}$ Email: finaputri358@gmail.com
}

\begin{abstract}
This study aims to explore the ability to reason students in statistical material. This is motivated by the ability to reason statistics class IX students have not yet reached the highest level at the level of reasoning ability. This research is a qualitative research. The instrument used consisted of statistical question sheets and interview guidelines compiled based on indicators of statistical reasoning ability. The results of the study indicate that students are still unsure of the answers to the problems because basically students still have a level of informal quantitative reasoning ability.
\end{abstract}

Keyword: Reasoning Ability, Statistics, Cooperative Models

\begin{abstract}
Abstrak: Penelitian ini bertujuan untuk mengeksplorasi kemampuan bernalar peserta didik pada materi statistika. Hal ini dilatarbelakangi oleh kemampuan bernalar statistika peserta didik kelas IX masih belum mencapai level tertinggi pada tingkatan kemampuan penalaran. Untuk mendalami fenomena tersebut dalam penelitian ini, peneliti memilih beberapa peserta kegiatan pelatihan tersebut sebagai subjek untuk penelitian yang lebih mendalam. Penelitian ini merupakan penelitian kualitatif. Instrumen yang digunakan terdiri dari lembar soal statistika dan pedoman wawancara yang disusun berdasarkan indikator kemampuan penalaran statistika. Hasil penelitian menunjukkan bahwa peserta didik masih ragu dengan jawaban dari permasalahan karena pada dasarnya peserta didik masih memiliki tingkat kemampuan bernalar kuantitatif informal.
\end{abstract}

Kata Kunci: Kemampuan Penalaran, Statistika, Model Kooperatif

\section{PENDAHULUAN}

Secara tidak disadari, kita selalu menggunakan statisika dalam berbagai aktivitas. Statistika dapat dipandang sebagai alat untuk memecahkan suatu masalah dalam kehidupan sehari-hari (Moree, 1997). Hampir semua aktivitas yang dilakukan manusia menggunakan statistika seperti perhitungan jumlah penduduk, perhitungan pengguna jejaring sosial, dan lainnya. Oleh karena itu, statistika sangat penting untuk dipelajari secara bermakna, supaya data yang ada dapat dipahami secara utuh dan menghasilkan penafsiran yang sesuai.

Salah satu cara memahami data dapat dilakukan dengan menggunakan penalaran statistik. Penalaran statistik merupakan aktivitas bernalar tentang materi statistika sehingga terbentuk keterampilan dalam menggunakan konsep-konsep statistik (Lanani, 2015: 5). Penalaran statistik sebagai cara memahami proses statistik secara keseluruhan sehingga menghasilkan informasi statistik (Ulfah, 2013: 13). Terbentuknya kemampuan penalaran peserta didik pada materi statistika mendukung peserta didik untuk mampu memahami konsep statistika serta dapat mengetahui pentingnya statistika dalam kehidupannya.

Kemampuan penalaran statistik terbentuk atas dasar teori konstruktivistik. Menurut teori pembelajaran konstruktivistik orang belajar dengan membangun pengetahuan, bukan dengan menerima pengetahuan (Garfield dan Ben-Zvi, 2007). Dengan kata lain pembelajaran dengan mengaitkan pembelajaran yang baru dengan yang 
lama yang sudah dipelajari, jadi pembelajaran sebelumnya tidak hilang begitu saja. Pembelajaran yang baik adalah pembelajaran yang dapat membuat peserta didik aktif karena peserta didik menggali pengetahuan berdasarkan pengalaman yang sudah ada.Kegiatan tersebut melibatkan peserta didik untuk banyak berpikir dan bernalar. Hal ini tidak berarti bahwa peserta didik berjalan tanpa adanya campur tangan guru, guru harus tetap membimbing peserta didiknya akan tetapi guru harus mendukung peserta didiknya untuk mencari pengetahuan untuk para peserta didiknya.

Pembelajaran kooperatif adalah pendekatan pembelajaran yang berfokus pada penggunaan kelompok kecil peserta didik untuk bekerjasama dalam memaksimalkan kondisi belajar untuk mencapai tujuan belajar (Nurhadi, 2004). Pembelajaran kooperatif adalah suatu sistem yang didalamnya terdapat elemenelemen yang terkait. Elemenelemen itu adalah saling tatap muka, saling ketergantugan positif, interaksi tatap muka, akuntabilitas individual dan ketrampilan untuk menjalin hubungan antar pribadi atau keterampilan sosial yang secara sengaja diajarkan (Ibrahim, 2000). Model pembelajaran kooperatif learning adalah suatu strategi dalam kegiatan belajar mengajar yang menekankan sikap dalam menyelesaikan suatu permasalahan atau saling memantu satu sama lain, kerjasama antar kelompok, yang terdiri dari dua orang atau lebih. Langkahlangkah dalam kegiatan belajar mengajar kooperatif learning yaitu: menyampaikan tujuan pembelajaran dan memotivasi peserta didik, menyajikan informasi, membagi peserta didik menjadi beberapa kelompok belajar, membimbing kelompok belajar, evaluasi, dan memberikan penghargaan di akhir pembelajaran.

Penelitian ini bertujuan untuk mengeksplorasi kemampuan bernalar peserta didik pada materi statistika. Hal ini dilatarbelakangi oleh dugaan bahwa kemampuan bernalar statistika peserta didik kelas IX masih belum mencapai level yang seharusnya. Untuk mendalami fenomena tersebut, peneliti memilih beberapa peserta kegiatan pelatihan tersebut sebagai subjek penelitian untuk di observasi secara mendalam terkait proses penalaran statistika yang digunakan.

\section{METODE}

Penelitian ini merupakan penelitian kualitatif, dimana instrument yang digunakan adalah lembar soal statistika yang berisi tentang permasalahan yang akan di berikan kepada subjek. Adapun lembar soal berisi permasalahan sebagai berikut "Diagram dibawah ini menyajikan data (dalam bilangan bulat) nilai sementara dari nilai ujian ulang mahasiswa peserta kuliah matematika. Ujian ulang di ikuti hanya oleh peserta kuliah tersebut dengan nilai sementara lebih kecil dari pada 6. Jika yang dinyatakan lulus kuliah adalah mahasiswa yang memperoleh nilai sementara tidak lebih dari pada 6 atau nilai ujian ulangnya adalah 6 , maka nilai rata-rata nilai mahasiswa yang lulus mata kuliah tersebut adalah ...

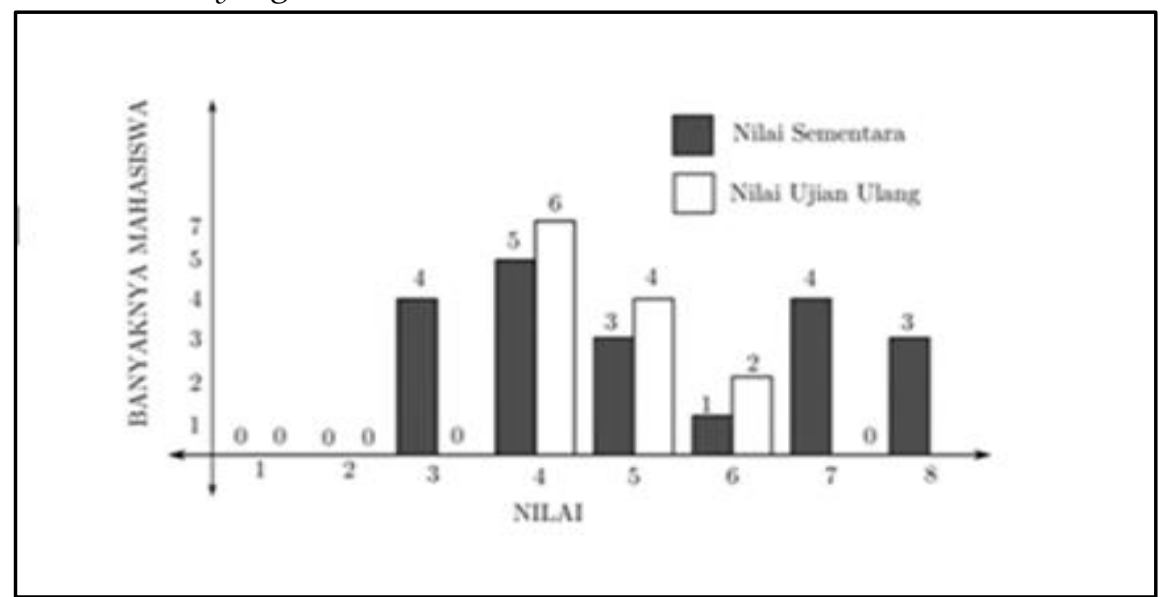

Gambar 1. Permasalahan yang Diberikan Kepada Peserta Didik 
Penelitian ini dilakukan pada semester ganjil 2019/2020.Sebelumnya, peneliti melakukan kegiatan pelatihan pendahuluan di Laboratorium Terpadu FKIP. Peneliti mengambil dua subjek dari kegiatan pelatihan untuk melakukan penelitian yang lebih mendalam. Teknik sampling yang digunakan adalah purposive sampling. Penelitian ini dilakukan selama Bulan Desember 2019. Pada tahap awal, peneliti memberikan soal kepada subjek dan peneliti akan mengamati cara subjek untuk mengerjakan soal tersebut. Setelah subjek selesai mengerjakan soal peneliti melakukan wawancara kepada subjek terkait indikator penalaran statistik yang sudah dirancang sebelumnya. Indikator kemampuan bernalar statistika yang digunakan dalam penelitian ini meliputi: mendeskripsikan data, mengorganisasikan data, merepresentasikan data, menganalisis dan menginterpretasikan data (Martadipura dan Suryadi, 2012). Adapun langkah-langkah penelitian secara garis besar dapat dilihat dalam flow chart pada Gambar 1.

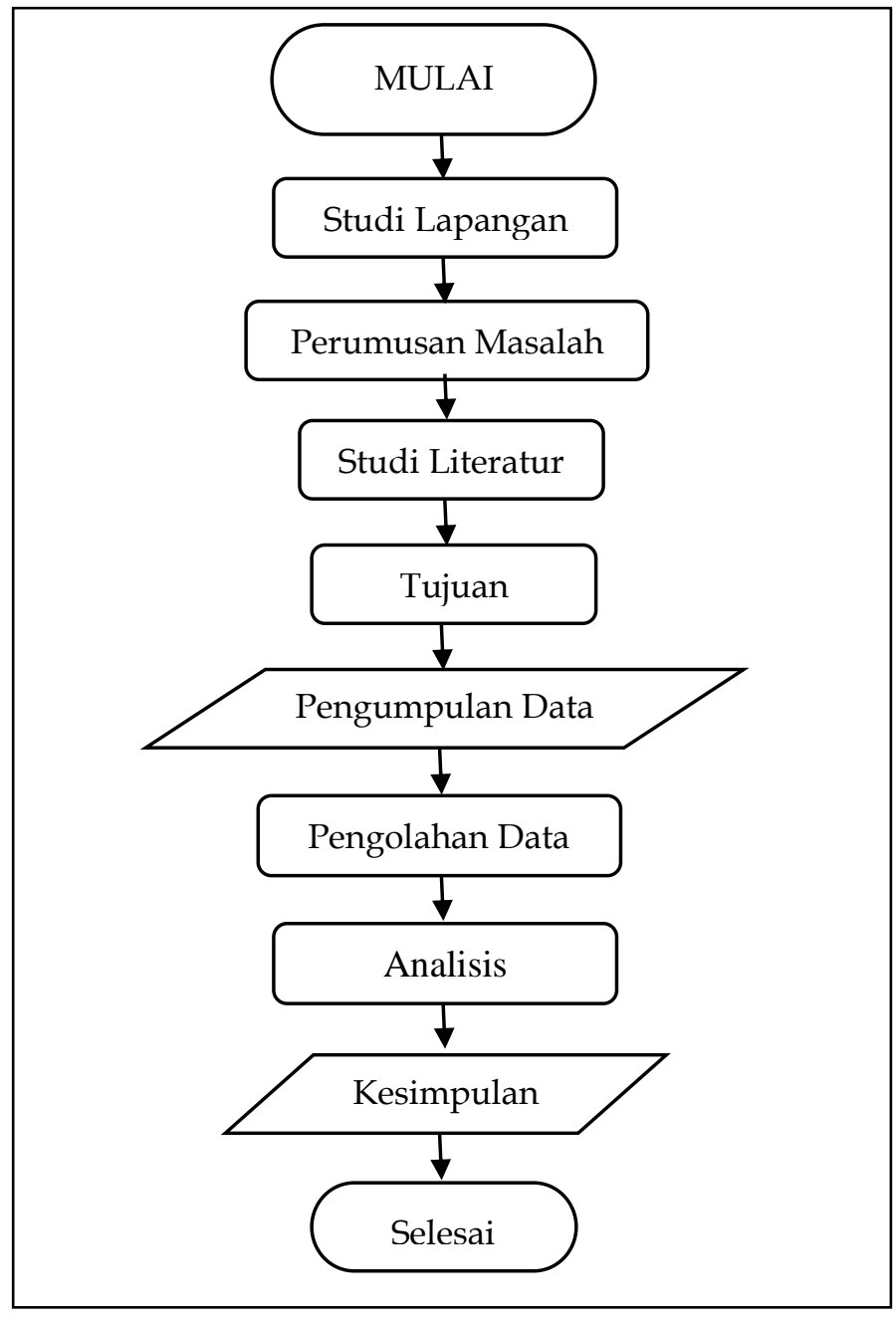

Gambar 2. Alur Penelitian

\section{HASIL DAN PEMBAHASAN}

Statistika merupakan salah satu kebutuhan manusia dalam memecahkan permasalahan kehidupan. Statistika dapat dipandang sebagai alat untuk memecahkan suatu masalah dalam kehidupan sehari-hari, tempat bekerja dan dalam ilmu pengetahuan (Moree, 1997). Hampir semua aktivitas-aktivitas yang dilakukan manusia menggunakan statistika, karena statistika dapat disimpulkan ialah kumpulan data yang berbentuk angka dan di susun dalam bentuk diagram atau pun table dimana isinya menjelaskan mengenai masalah tertentu. Statistik juga sering kali digunakan untuk melakukan 
penelitian di berbagai bidang, statistik ini berguna untuk menyusun data-data ataupun angka setelah dilakukannya penelitian ataupun pengamatan, misalnya saja dalam bidang ekonomi, bisnis, manufaktur, pemasaran dan bidang kehidupan lainnya. Statistik juga dapat di temukan di dunia pendidikan, biasanya statistik ini di temukan pada pembelajaran matematika, dimana pembelajaran matematika tentang statistik ini akan mengajarkan tentang mean, modus, median dan grafik histogram maupun grafik pie.

Pembelajaran kooperatif merupakan salah satu model pembelajaran yang menganut paham kontruktivis. Pembelajaran kooperatif adalah suatu model pembelajaran yang mana peserta didik belajar dan bekerja dalam kelompok-kelompok kecil dan kolaboratif dengan struktuk kelompok heterogen (Slavin,1995). Pembelajaran kooperatif dapat digunakan dalam berbagai bidang pendidikan dan dalam semua jenjang pendidikan. Model kooperatif juga dapat digunakan untuk pembelajaran matematika, dimana nantinya kelompok-kelompok kecil tersebut terdiri dari peserta didik yang memiliki kemampuan berbeda, dimana setiap peserta didik memiliki tingkat kemampuan bernalar terhadap matematika secara berbeda.

Polaki (2005) merumuskan bahwa ada beberapa tingkatan untuk dapat mengidentifikasi tingkat penalaran statistik yang di miliki oleh seseorang, tingkatan ini memiliki 5 level. Level 0 : subjek tidak memberikan jawaban terhadap masalah yang diberikan; Level 1 (Penalaran subjek) : Subjek mengabaikan informasi numerik, yang digunakan untuk mengevaluasi masalah; Level 2 (Penalaran Transisional) : Subjek dapat berpikir positif secara politis namun tidak sesuai dalam penggunaan angka; Level 3 ( Penalaran kuantitatif informal) : subjek mampu mengidentifikasi semua masalah tetapi subjek tidak mengaitkan semua bagian permasalahan; Level 4 (Penalaran Numerik ) : subjek menyatakan hal yang terkait pada soal, subjek dapat menetapkan angka yang tepat dan benar dengan membedakan antara masalah pada soal dan bukan.

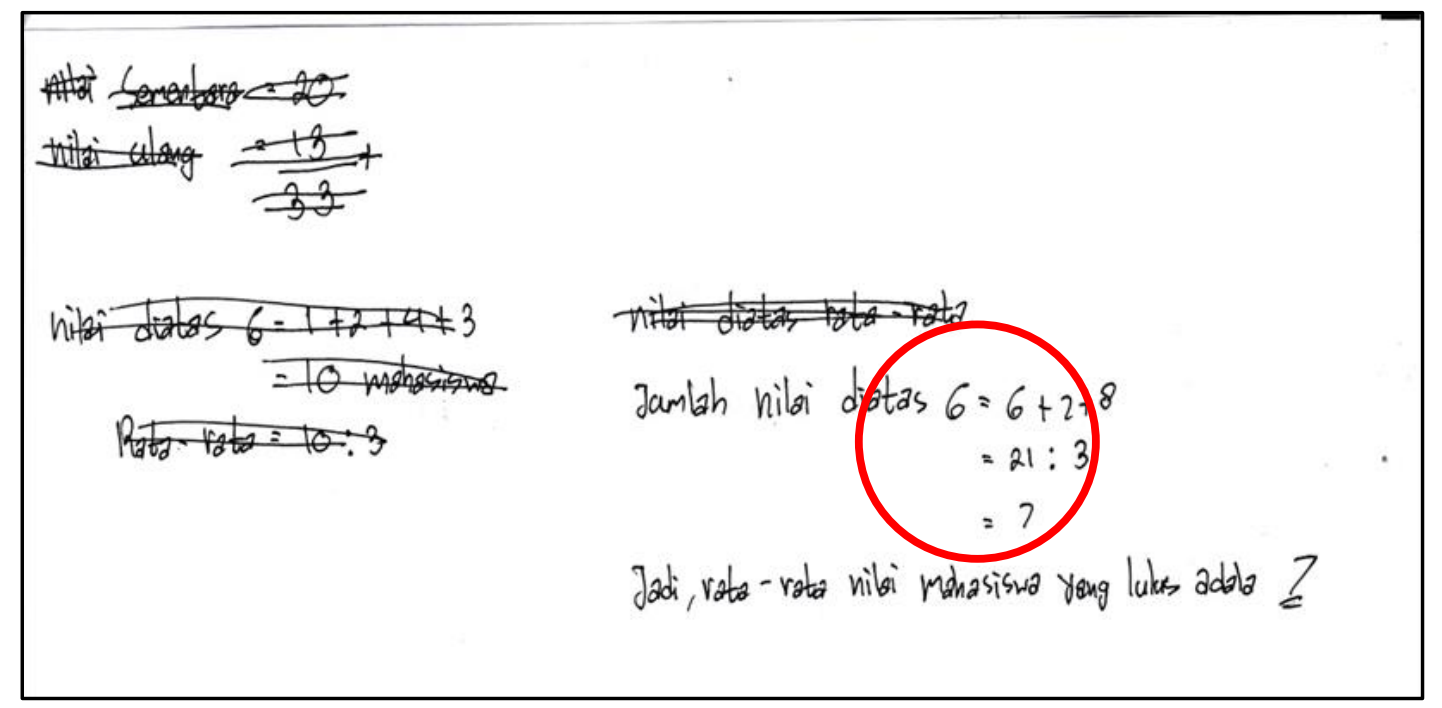

Gambar 3. Hasil Pengerjaan Peserta didik

Dari hasil pengamatan pertama yang dilakukan oleh peneliti, menunjukkan bahwa subjek tidak menggunakan istilah diketahui, ditanya dan jawab untuk mengidentifikasi masalah yang ada pada soal. Subjek hanya menuliskan angka yang tertera pada grafik soal tanpa memberi keterangan yang detail. Dari hasil pekerjaan subjek dapat dilihat pula bahwa subjek hanya menggunakan rumus dan menghitung secara sederhana. Hal ini mengakibatkan subjek kurang teliti dalam mengerjakannya, itu dibuktikan dengan lingkaran berwarna merah yang menunjukan bahwa subjek kurang teliti dalam perhitungan yang subjek buat. 
Pada Gambar 3, dapat disimpulkan bahwa subjek masih memiliki tingkat kemampuan bernalar kuantitatif informal. Dimana penalaran kuantitaif informal adalah penalaran yang hanya fokus pada satu atau inti permasalahan tanpa mengitkan seluruh komponen bagian dari permasalahan. Disisi lain, subjek tidak merasa kesulitan dalam menentukan masalah yang ada dalam persoalan tersebut, hanya saja subjek sedikit bingung dengan kalimat soal yang menurut subjek berbelit-belit dan tidak efisien pada kalimatnya. Hal Ini ditunjukkan dari hasil wawancara peneliti terhadap subjek setelah mengerjakan soal sebagai berikut :

$\mathrm{P}$ : "Setelah mengerjakan soal tersebut, apa yang anda ketahui mengenai permasalahan pada soal ?"

S : "Eemm... setelah saya mengerjakannya, saya bingung dengan kalimat-kalimatnya."

P : "Lalu dengan soal seperti itu, bagaimana anda dapat menyelesaikannya?"

S : "Saya mengerjakan soalnya tidak menggunakan rumus, jadi saya menghitungnya dengan cara saya sendiri."

$\mathrm{P}$ : "Kenapa anda tidak menggunakan rumus, padahal kan soal tersebut pasti ada rumusnya?"

S : "Karena, saya bingung saat membaca kalimatnya."

$\mathrm{P}$ : "Kalau boleh tau, kalimat yang manakah yang membuat anda bingung saat mengerjakannya?"

S : "Yang ini kak, (jika yang dinyatakan lulus kuliah adalah mahapeserta didik yang memperoleh nilai sementara tidak lebih kecil daripada 6 atau nilai ujian ulangnya adalah 6)."

P : "Memangnya ada apa dengan kalimatnya, kan sudah jelas dari kalimat tersebut."

S : "Apa ya kak? Eemm.. Saya bingung memahami kalimat-kalimat tersebut, terlalu berbelit-belit."

$\mathrm{P} \quad$ : "Bagaimana anda dapat menyelesaikannya tanpa menggunakan rumus?"

S : "Ya, gini kak. Saya melihat gambar diagramnya, lalu dilihat antara nilai dan banyaknya mahapeserta didik itu saya jumlahkan dan akhirnya ketemu deh jawabannya tujuh."

$\mathrm{P}$ : "Lalu, apakah ada lagi yang membuat anda bingung dalam pengerjaan soal ?"

S : "Ada kak, ini lo kak, saya bingung membedakan antara frekuensi nilai sementara dan nilai ulang."

$\mathrm{P}$ : "Setelah mengerjakan soal, apakah anda yakin dengan jawaban anda?"

S : "Ya, saya yakin. Walaupun agak sedikit kebingungan."

Dari hasil wawancara bersama subjek yang telah selesai mengerjakan soal, dapat diketahui bahwa subjek tidak menggunakan rumus untuk menyelesaikan persoalan tersebut, subjek hanya berpatokan pada grafik dan nilai yang ditunjukkan dari grafik tersebut. Subjek juga mengatakan bahwa subjek sedikit bingung ketika akan menentukan frekuensi, antara nilai sementara dan nilai ulang.

Menurut Garfield (2002) sebuah model penalaran statistik memiliki lima level dan disusun secara hierarkis sebagai berikut:

1. Penalaran Idiosyncratic

Mengetahui simbol dan istilah statistika, namun belum memahami penggunaannya.

Sebagai contoh, peserta didik telah mempelajari rerata, median, dan simpangan baku sebagai ukuran ringkasan suatu data, tetapi penggunaannya tidak benar.

2. Penalaran verbal 
Mempunyai pemahaman verbal dari beberapa konsep, namun belum dapat mengaplikasikannya. Contohnya, peserta didik dapat mendefinisikan suatu konsep dengan tepat namun pemahaman konsep tersebut secara utuh tidak dimilikinya.

3. Penalaran Transitional

Mempunyai kemampuan untuk mengidentifikasi secara benar beberapa konsep statistika, namun pemahaman dari konsep-konsep tersebut tidak terintegrasi secara utuh/menyeluruh.

4. Penalaran Prosedural

Mempunyai kemampuan untuk mengidentifikasi secara benar konsep-konsep statistika, namun aplikasi dari konsep itu belum terintegrasi secara utuh.

5. Penalaran Proses Terintegrasi

Mempunyai pemahamanlengkap tentang konsep-konsep statistika, hubungan dengan konsep lain dan aplikasinya, serta mampu memberikan penjelasan tentang suatu konsep dengan menggunakan kalimat sendiri.

Dari hasil pengerjaan dan wawancara yang telah di lakukan peneliti terhadap subjek setelah mengerjakan permasalahan yang di berikan, menunjukkan bahwa subjek memiliki tingkat penalaran matematis transitional, karena pada Gambar 3 menunjukan bahwa subjek hanya bisa mengidentifikasi beberapa konsep statistika dengan benar. Hal yang sama juga di tunjukkan dari hasil wawancara peneliti terhadap subjek yang menunjukkan bahwa subjek belum dapat mengintegrasi secara utuh dan menyeluruh tentang pemahaman konsep-konsep permasalahan yang di berikan. Hal Ini dibuktikan dengan subjek yang tidak dapat mencerna maksud dari kata-kata yang disajikan dalam permasalahan, seperti pada Gambar 1 disana subjek merasa kesulitan dengan kata-kata yang menurutnya terlalu berbelit-belit dan tidak efisien yang menyebabkan subjek sulit untuk mengidentifikasi dan melakukan penalaran terhadap permasalahan statistika yang diberikan.

\section{SIMPULAN}

Pembelajaran kooperatif adalah suatu model pembelajaran yang mana peserta didik belajar dan bekerja dalam kelompok-kelompok kecil secara kolaboratif dan mendorong peserta didik saling menciptakan interaksi yang asah, asih asuh (saling mencerdaskan). Dari hasil yang telah di peroleh pada penelitian yang telah dilakukan oleh peneliti, menunjukkan bahwa penalaran statistik pada peserta didik kelas IX masih belum mencapai level tertinggi pada tingkatan kemampuan penalaran. Dimana peserta didik tergolong kedalam level 3 (Penalaran Kuantitatif Informal), yaitu subjek mampu mengidentifikasi semua masalah tetapi subjek tidak mengaitkan semua bagian permasalahan. Subjek yang diambil sebagai sampel ada dua orang, namun penelitian ini juga dilakukan dengan beberapa subjek lainnya. Penalaran matematika dalam statistika belum dapat dikatakan baik, karena subjek masih mempunyai penalaran yang rendah, yang hanya fokus pada satu atau inti permasalahan tanpa mengaitkan seluruh komponen bagian dari permasalahan. Dengan demikian subjek membutuhkan perhatian khusus dari seorang pendidik yang profesional agar pembelajaran dapat berjalan dengan baik.

\section{UCAPAN TERIMA KASIH}

Ucapan terima kasih terutama ditujukan kepada seluruh dosen dan staff Laboratorium Terpadu Fakultas Keguruan dan Ilmu Pendidikan, Universitas Islam Malang yang telah memfasilitasi pelaksanaan kegiatan penelitian ini.

\section{DAFTAR PUSTAKA}

David S Moree, "New Pedagogy and New Content: The Case of Statisstics", International Statistics Review, 65 Nomor 2 (1997) Hal 123-165 
Garfield, J. (2002). The Challenge of Developing Statistical Reasoning.Journal of Statistics Education Volume 10, Number 3, hal 10

Garfield, J. and Ben-Zvi, D. (2007). How Student Learn Statistics Revisited: A Current Review of Research on Teaching and Learning Statistics. International Statistical Review, 75(3), 372-396

Ibrahim, M., \& dkk. (2000). Pembelajaran Kooperatif .Surabaya: Universitas Negeri Surabaya.

Karman Lanani, Desertasi Doktor: “ Kemampuan Penalaran Statistis, Komunikasi Statistis dan Academic Help-Seeking Mahapeserta didik dalam Pembelajaran Berbasis Proyek Berbantuan ICT" (Universitas Pendidikan Indonesia, 2015), 5

Maria Ulfah, Thesis: "Peningkatan Kemampuan Penalaran Statistis Dan SelfEfficacy Peserta didik Madrasah Aliyah Melalui Pembelajaran Kontekstual", (Bandung: Universitas Pendidikan Indonesia.2013), hal 13

Martadipura, Bambang Avip Priatna dan Didi Suryadi.(2012). “Peningkatan Kemampuan Berpikir Statistis Mahapeserta didik S1 Melalui Pembelajaran MEAs yang Dimodifikasi". Infinity: Jurnal Ilmiah Program Studi Matematika STKIP Siliwangi Bandung. 1(1), 79-89.

Nurhadi. (2011). Kurikulum 2004 Pertanyaan dan Jawaban . Gasindo In Seminar Nasional LPM UNY , 1-10. 